\title{
Variability and changes in selected climate elements in Madrid and Alicante in the period 2000-2014
}

\author{
Katarzyna Cielecka
}

Department of Climatology, Faculty of Earth Sciences, University of Silesia, 60 Bedzinska Str, 41-200

Sosnowiec, Poland;

katarzyna.cieleckal@gmail.com

Received: $19^{\text {th }}$ October, 2015

Accepted: $5^{\text {th }}$ January, 2016

\begin{abstract}
The aim of this study is to compare climatic conditions between the interior of the Iberian Peninsula and the southeastern coast of Spain. The article analyzes selected elements of climate over the last 15 years (2000-2014). Synoptic data from airport meteorological stations in Madrid Barajas and Alicante Elche were used. Attention was focused on annual air temperature, relative humidity and precipitation. The mean climatic conditions over the period 2000-2014 were compared with those over the 1961-1990 period which is recommended by WMO as climate normal and with data for the 1971-2000 coming from 'Climate Atlas' of Spanish meteorologists group AEMET. Two of climate elements discussed were characterized by significant changes. The annual air temperature was higher by about $0.2^{\circ} \mathrm{C}$ in Alicante and $0.9^{\circ} \mathrm{C}$ in Madrid in the period 2000-2014 compared to the 1961-1990. The current winters were colder than in years 1961-1990 at both stations. Gradual decrease in annual precipitation totals was observed at both stations. In 1961-1990 the annual average precipitation in Madrid amounted to 414 $\mathrm{mm}$, while in Alicante it was $356 \mathrm{~mm}$. However, in the recent years of 2000-2014 these totals were lower compared to 1961-1990 reaching $364.1 \mathrm{~mm}$ in the central part of Spain and $245.7 \mathrm{~mm}$ on the south-western coast.
\end{abstract}

Key words: Mediterranean Region, air temperature, precipitation, relative humidity, Iberian Peninsula.

\section{Introduction}

The climate of the Mediterranean region makes the Iberian Peninsula an attractive tourist destination. Spain, located in the southern part of Europe, is an area where the climate is relatively stable throughout the year. However, it long-term changes are manifested by a progressive drying out of this area. The Iberian Peninsula is also visited by tourists who could be interested in climatic conditions of Madrid and Alicante. Therefore, the aim of this study is to assess the spatial variability and temporal changes of climatic conditions.

Climatic condition of the Iberian Peninsula with respect to precipitation has been discussed by Rodrigo 2010, Martin-Vide and LopezBustins 2006, Gallego et al. 2006, Goodess and Palutikof 1998. These papers concern extreme precipitation events - changes in their frequency and intensity, or relation between rainfall and atmospheric circulation. Annual course and long-term variability of air temperature and atmospheric precipitation was described by Spanish meteorologists group from AEMET (2012). The authors drew attention to droughts occurring in south-eastern areas of the Iberian Peninsula. Many attention has already been paid to air temperature (Brunet et al. 2007, AEMET 2012) or its relation to atmospheric circulation (Kenawy et al. 2012). Spanish climate is also well described by Linés Escardó (1970) and Martyn (1992,1995).

\section{Data and methods}

This study is based on daily values of air temperature, relative humidity and atmospheric precipitation measured at eight synoptic terms: 00, 03, 06, 09, 12, 15, 18, 21 UTC taken from following meteorological stations: Adolfo Suarez Madrid Barajas Airport $(\varphi=$ 
40²9'16'” N, $\lambda=3^{\circ} 33^{\prime} 38^{\prime \prime} \mathrm{W}$, WMO No 08221, $609 \mathrm{~m}$ a.s.1.), and Alicante Elche Airport ( $\varphi=38^{\circ} 16^{\prime} 56^{\prime}$ ' $\mathrm{N}, \lambda=0^{\circ} 33^{\prime} 29^{\prime}$ ' $\mathrm{W}$, WMO No 08360, $43 \mathrm{~m}$ a.s.1.) (Fig. 1).

The data covers the period from December 1999 to December 2014 and comes from OGIMET database (Valor and López 2015). The series of relative humidity for the station in Alicante was incomplete. The periods with missing data $(08.12 .2000, \quad 14.12 .2000$, 09.05.2000, $\quad 04.12 .2002, \quad 05.12 .2002$, 06.12.2002, 31.07.2006, $\quad$ 01.08.2006, 30.10.2008, 18.03.2009, 19.03.2009, 29.03.2009, 30.03.2009, 24.03.2010) were excluded from the analysis. The gaps were not possible to be filled in due to lack of available data. In case of air temperature and precipitation, the gaps in data were completed by data from ECA\&D database (Klein Tank et al. 2012). To do so data from neighbouring stations were used (08224 Madrid Getafe, 08359 Alicante).

This sub-daily data were used to calculate annual air temperature (T), monthly averages air temperature, extremes of air temperature $\left(\mathrm{T}_{\min } / \mathrm{T}_{\max }\right)$ and daily air temperature range (DTR). The set of percentiles $(99,90,75,50$, 25,10 and 1 percentile) were also calculated from daily values on monthly scale. In the case of relative humidity $(\mathrm{RH})$, the annual, monthly and minimum values were analyzed. Additionally, the number of dry days defined as days with humidity $\mathrm{f}_{\min } \leq 50 \%$, and very dry days with minimum relative humidity $\leq 30 \%$, were calculated. Annual totals of precipitation, monthly averages and its extremes were also researched.

Moreover anomalies of air temperature and precipitation in the period 2000-2014 from the climatic norms of 1961-1990 (WMO 1996) and 1971-2000 (AEMET 2012) were calculated for both stations.

\section{Air temperature}

\section{Annual air temperature}

The annual air temperature in the period 20002014 amounted to $14.8^{\circ} \mathrm{C}$ in Madrid, while in Alicante $18.1^{\circ} \mathrm{C}$ (Tab. 1). The south-east coast was warmer by about $3.3^{\circ} \mathrm{C}$ than the interior of Spain in recent period. The reason for lower air temperature in Madrid is its height above sea level. This station is located $566 \mathrm{~m}$ higher than Alicante. In turn, the mild conditions of the Mediterranean Sea have influence on higher air temperature at the Alicante station.

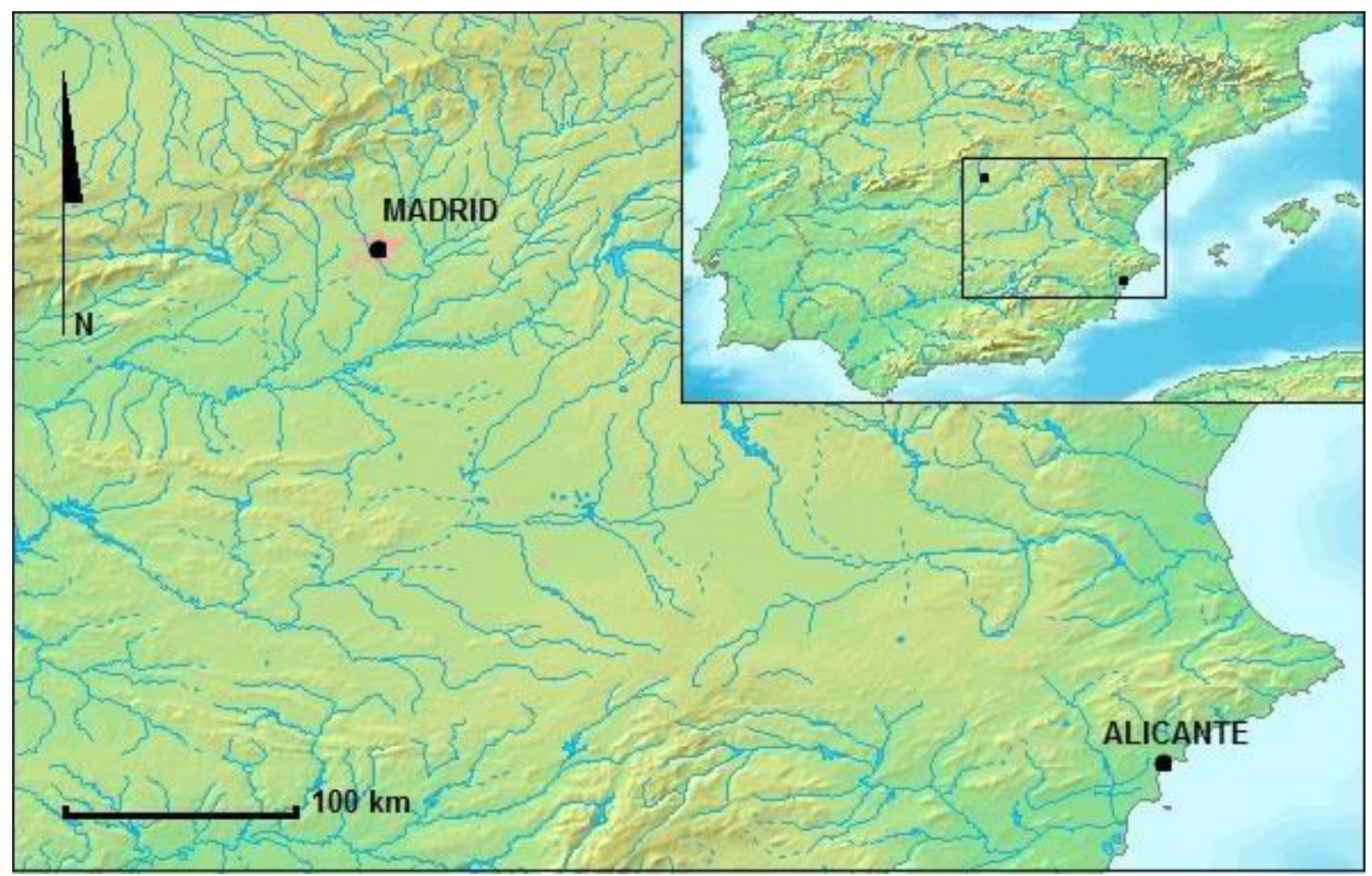

Fig.1. Location of meteorological stations: Madrid Barajas and Alicante Elche in the Iberian Peninsula. 
Tab.1. Monthly and annual average air temperature $\left[{ }^{\circ} \mathrm{C}\right]$ in period 1961-1990 and 2000-2014.

\begin{tabular}{|c|c|c|c|c|c|c|c|c|c|c|c|c|c|c|}
\hline & Period & I & II & III & VI & V & VI & VII & VIII & IX & $X$ & XI & XII & I-XII \\
\hline \multirow{3}{*}{ Alicante } & $1961-1990$ & 11.6 & 12.4 & 13.7 & 15.7 & 18.6 & 22.1 & 25.1 & 25.5 & 23.3 & 19.2 & 14.9 & 12.1 & 17.9 \\
\hline & $2000-2014$ & 11.2 & 11.6 & 13.8 & 16.0 & 19.1 & 23.3 & 25.8 & 26.2 & 23.5 & 19.8 & 14.7 & 11.8 & 18.1 \\
\hline & Deviation from normals & -0.4 & -0.8 & +0.1 & +0.3 & +0.5 & +1.2 & +0.7 & +0.7 & +0.2 & +0.6 & -0.2 & -0.3 & +0.2 \\
\hline \multirow{3}{*}{ Madrid } & $1961-1990$ & 5.5 & 7.0 & 9.3 & 11.6 & 15.5 & 20.4 & 24.3 & 23.8 & 20.3 & 14.5 & 8.9 & 5.9 & 13.9 \\
\hline & $2000-2014$ & 5.4 & 6.7 & 10.1 & 12.9 & 17.1 & 23.2 & 25.9 & 25.5 & 20.9 & 15.1 & 9.1 & 5.5 & 14.8 \\
\hline & Deviation from normals & -0.1 & -0.3 & +0.8 & +1.3 & +1.6 & +2.8 & +1.6 & +1.7 & +0.6 & +0.6 & +0.2 & -0.4 & +0.9 \\
\hline
\end{tabular}

\section{Monthly air temperature}

The highest monthly average air temperature in Madrid usually occurs in July $\left(25.9^{\circ} \mathrm{C}\right)$ while in Alicante in August $\left(26.2^{\circ} \mathrm{C}\right)$. At the Madrid station, January is usually the coldest month of year $\left(5.4^{\circ} \mathrm{C}\right)$. In Alicante, the minimum of air temperature occurs, similar like in Madrid, in the first month of the year $\left(11.2^{\circ} \mathrm{C}\right)$ (Tab. 1). According to Martyn (1995) on the south-east coasts of the Valencia and Murcia Province, the average air temperature in January reach similar value of $10^{\circ} \mathrm{C}$ in January.

\section{Percentiles of daily air temperature}

Extreme of probabilistic characteristics (99th and 1st percentiles) calculated for January indicate that daily temperature may either exceed $11.6^{\circ} \mathrm{C}$ (Madrid) and $17.8^{\circ} \mathrm{C}$ (Alicante) or be lower than $-2.7^{\circ} \mathrm{C}$ (Madrid) and $3.2^{\circ} \mathrm{C}$ (Alicante) once a 100 days. In July, this characteristics can reach $30.5^{\circ} \mathrm{C}$ (Madrid) or $28.7^{\circ} \mathrm{C}$ (Alicante) in case of $99^{\text {th }}$ percentiles and $17.5^{\circ} \mathrm{C}$ (Madrid) and $22.4^{\circ} \mathrm{C}$ (Alicante) in case of $1^{\text {st }}$ percentile (Fig. 2).

\section{Maximum and minimum daily air temperature}

According to Martyn (1995), the absolute maximum air temperature on the Iberian Peninsula can reach $50^{\circ} \mathrm{C}$ and it can amount to $42^{\circ} \mathrm{C}$ in Madrid. In the research period (20002014) the highest maximum temperature reached $40.9^{\circ} \mathrm{C}$ in Madrid ( $10^{\text {th }}$ of August 2012) and $39.1{ }^{\circ} \mathrm{C}$ in Alicante $\left(27^{\text {th }}\right.$ July 2003). The minimum air temperature on the Iberian Peninsula may be as low as $-30^{\circ} \mathrm{C}$ which was noted in Calamocha in the Iberian Mountains (Martyn 1995). In the research period the absolute minimum of air temperature was much higher, equaling to $-10.5^{\circ} \mathrm{C}\left(17^{\text {th }}\right.$ December 2012) in Madrid and $-1.9^{\circ} \mathrm{C}\left(31^{\text {st }}\right.$ January 2005$)$ in Alicante.

\section{Daily temperature range (DTR).}

The difference in climatic conditions of the stations are well depicted by daily temperature range which was calculated for every month in the period 2000-2014. Daily temperature range (or DTR) is defined as the difference between average maximum and minimum temperature (Del Rio et al. 2007). Daily temperature range varied from $9.5^{\circ} \mathrm{C}$ in January to $16.7^{\circ} \mathrm{C}$ in July at the Madrid station and from $8.9^{\circ} \mathrm{C}$ (JulySeptember) to $10.3^{\circ} \mathrm{C}$ in March at Alicante station. The DTR increased progressively along with the increase in the distance from large water reservoirs. Daily temperature range also appears to be a appropriate gauge of climate variability and change (Braganza et al. 2004). The greatest differences between the stations in daily temperature range occurred in the summer months (June-August). In Madrid, the high DTR was found in June $\left(16.2^{\circ} \mathrm{C}\right)$, July $\left(16.7^{\circ} \mathrm{C}\right)$ and August $\left(16.4^{\circ} \mathrm{C}\right)$ while in Alicante, in the same months, the DTR was lower reaching 
$9.6^{\circ} \mathrm{C}$ (June), $8.9^{\circ} \mathrm{C}$ (July) and $8.9^{\circ} \mathrm{C}$ (August) (Fig. 3). The high DTR in the summer and low DTR in autumn-winter period are a typical feature of Mediterranean climate well represented by Madrid. The annual course of DTR in Alicante is rather flat.

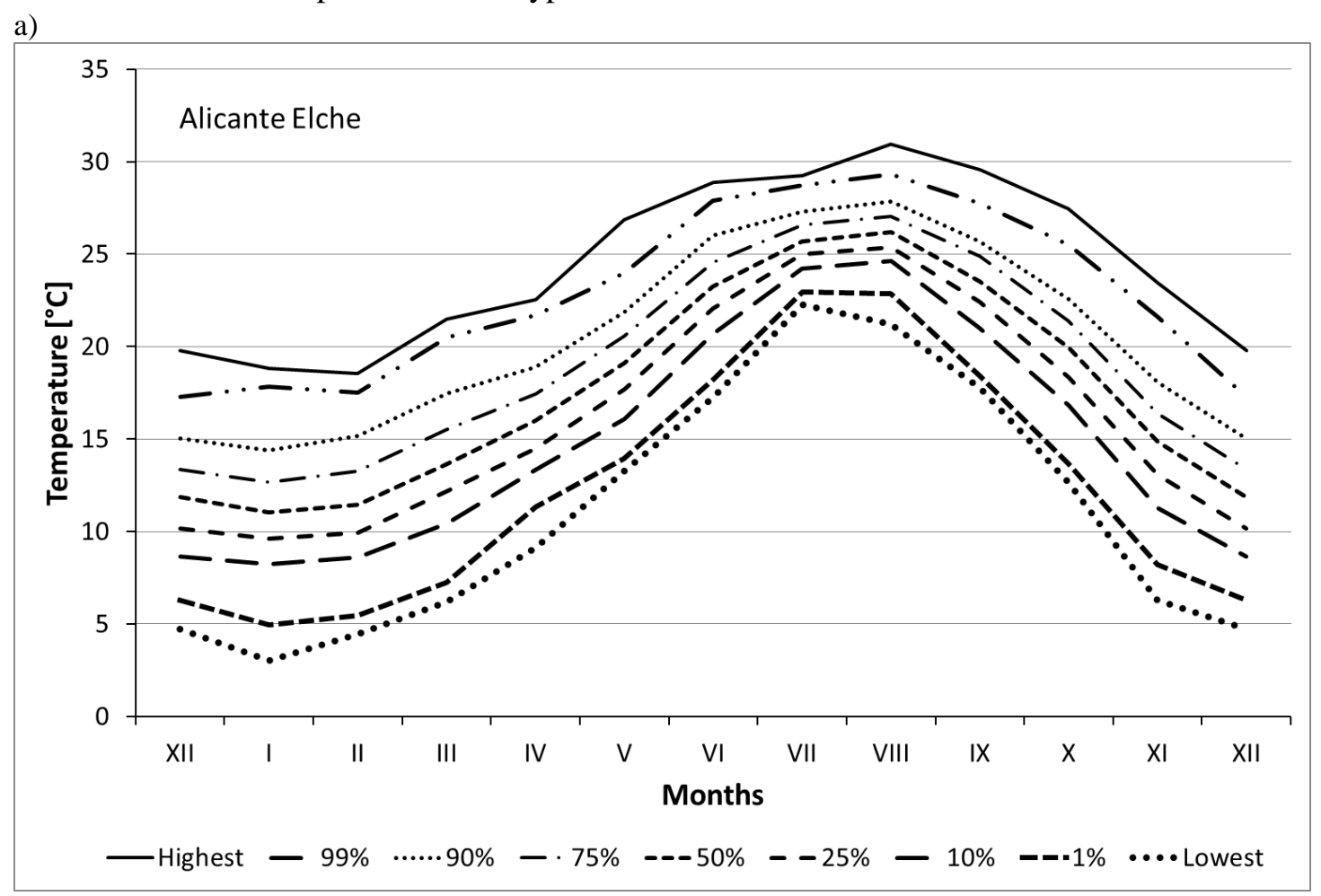

b)

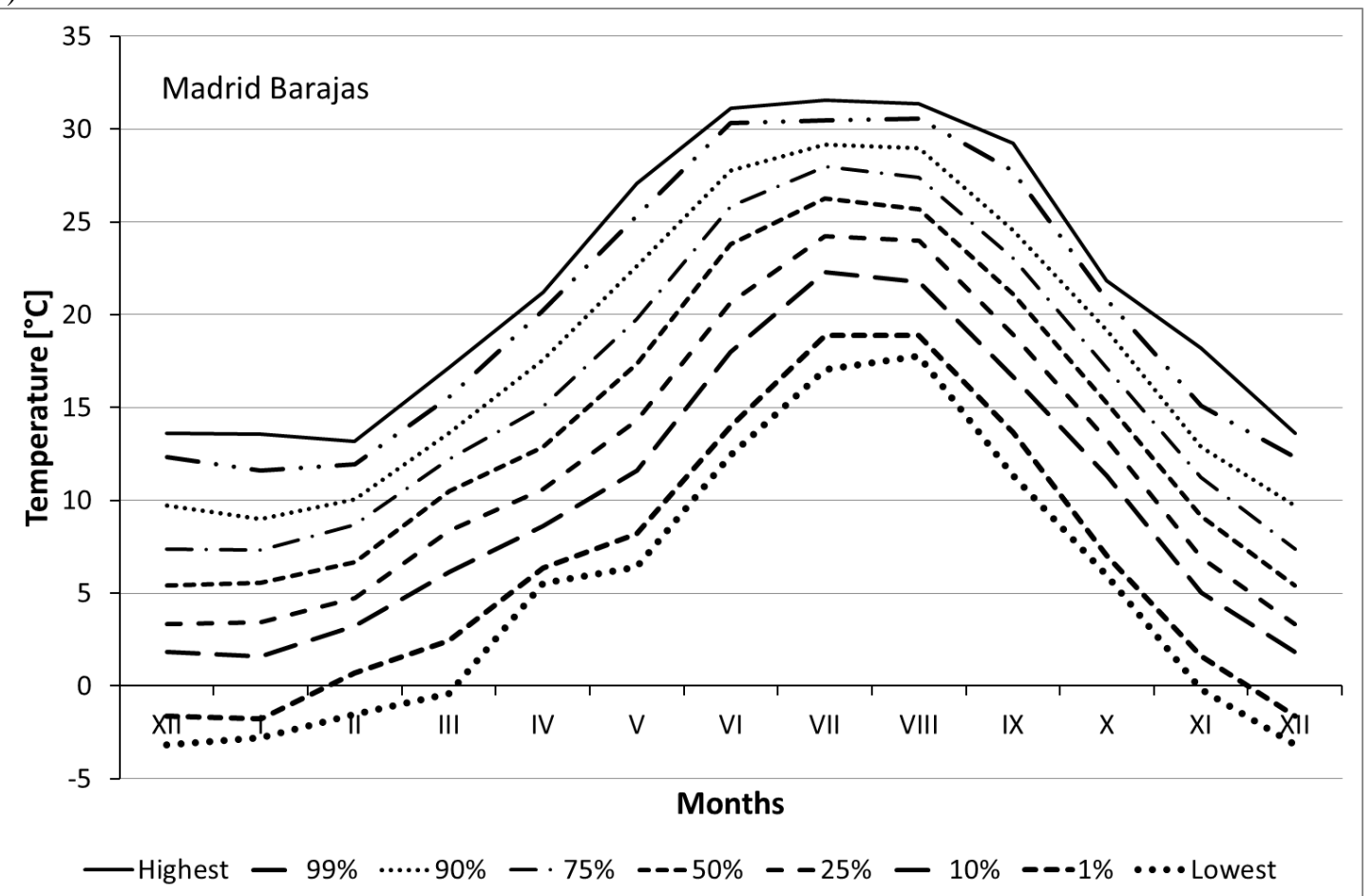

Fig.2. Percentiles from daily average temperature in: a) Alicante Elche, b) Madrid Barajas in the period 2000-2014 


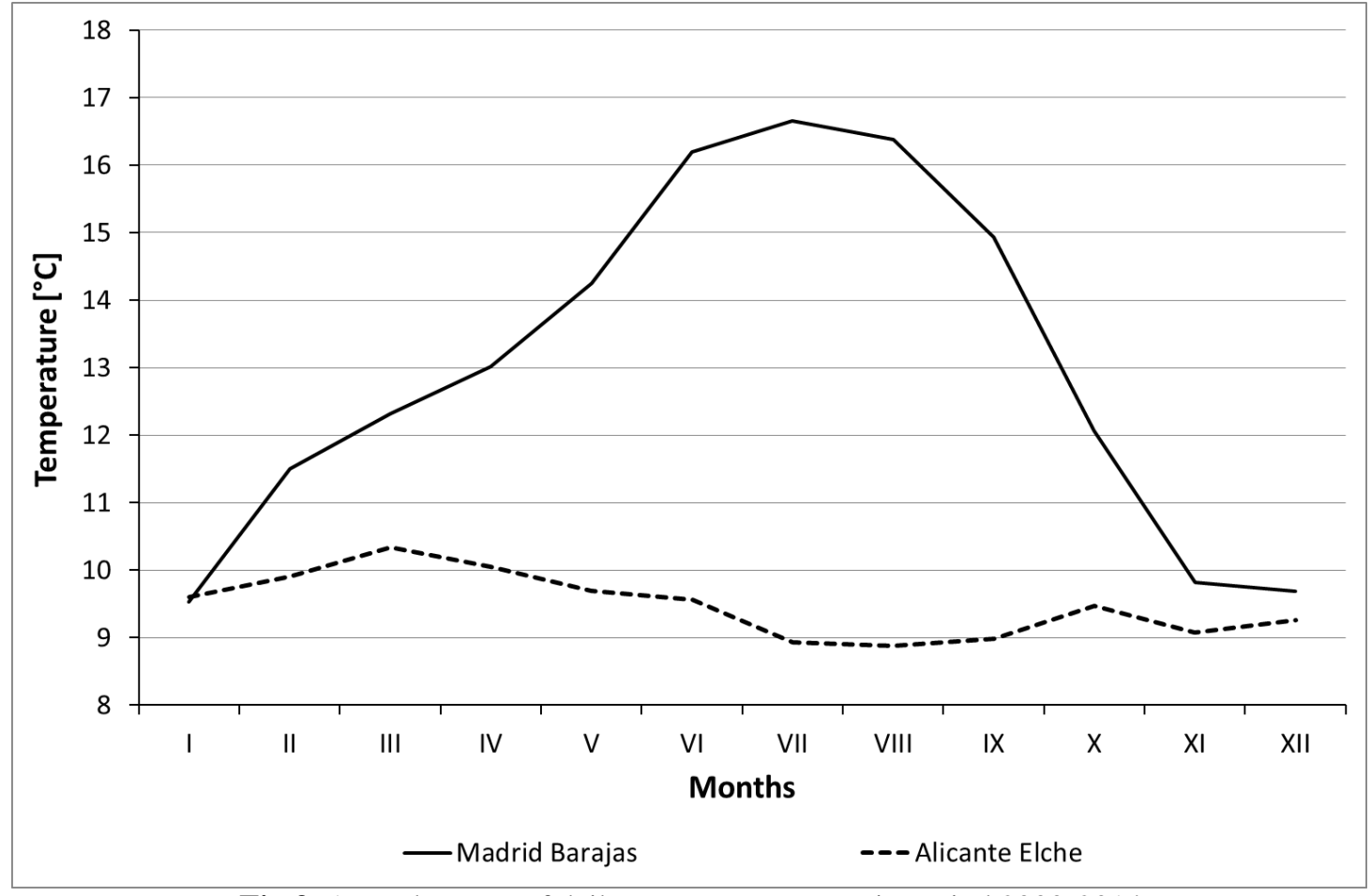

Fig.3. Annual course of daily temperature range in period 2000-2014.

\section{Relative humidity (RH)}

\section{Annual relative humidity}

Annual RH in Madrid (57\%) is slightly lower than in Alicante (63\%) however differences in monthly averages are notable in summer months. In Madrid summer RH (on average $36 \%$ ) is about $26 \%$ lower than in Alicante (on average $62 \%$ ). In winter the difference does not exceed $11 \%$ and it results from $74 \%$ in Madrid and $63 \%$ in Alicante (Fig. 4).

\section{Minimum relative humidity}

Exceptionally low RH amounting only to $3 \%$ in Alicante was noted on $31^{\text {st }}$ January 2003. Absolute minimum in Madrid reached hardly higher value of $5 \%$ and was recorded on $1^{\text {st }}$ August 2012. This extremely low value of relative humidity in Alicante occurred at 15 UTC during strong winds from NNW $\left(14 \mathrm{~m} \mathrm{~s}^{-1}\right)$ which descended from the surrounding hills to the coast and caused foehn effect. This wind resulted from the large pressure gradient between low-pressure area (994 hPa) located over Gulf of Lion and the strong Atlantic high- pressure area $(1046 \mathrm{hPa})$ with center located to the north of Madeira.

\section{The number of dry and very dry days}

In Madrid dry days constitute about $72 \%$ of days in the year (265 dry days). The frequency of very dry days is also high reaching 157 days in the year $(43 \%)$. In Alicante the number of these days amounted to 217 dry days $(59 \%)$ and 61 very dry days (16\%) (Tab. 2).

In Madrid monthly number of dry days is very high from May to September (27-31 days) and they occur almost every day in July and August. The least number of dry days usually occur in November, December and January. In Alicante, monthly number of dry days vary between 15 days in September to 21 days both in March and June. In Madrid a gradual increase in the number of dry days was observed from May to August and decrease from October to January. In Alicante the frequency of dry days did not change significantly in the annual course. A slight decrease in their frequency was observed from July (17 days) to September (15 days) (Tab. 2). In Alicante very dry days occurred very rarely and were characterised by low annual range varying from 2 in December 
to 8 in March in the research period. Lower air humidity in Madrid translated into much higher number of very dry days. The average number of these days ranged from 25 to 30 days between June and August. They were also quite frequent in September (22 days) and May (15 days). In the remaining months, very dry days varied from 1 day in December and January to 10 days in April (Tab. 2).

\section{Precipitation}

\section{Annual precipitation}

According to Martyn (1995), on the Mediterranean coast the annual average precipitation amounts to around $200 \mathrm{~mm}$. In years 2000-2014 the annual average total of atmospheric precipitation in Alicante was 245.7 $\mathrm{mm}$, while in Madrid it was $364.1 \mathrm{~mm}$ (Tab. 3).

Tab.2. The average of number of dry days $\left(f_{\min } \leq 50 \%\right)$ and very dry days $\left(f_{\min } \leq 30 \%\right)$ noted at Madrid and Alicante stations in particular months in 2000-2014.

\begin{tabular}{lccccccccccccc}
\hline \multicolumn{1}{c}{ Dry days } & \multicolumn{1}{c}{10} & & & & & & & & & & & \\
\hline Station & I & II & III & IV & V & VI & VII & VIII & IX & X & XI & XII & I-XII \\
\hline Alicante & 19 & 18 & 21 & 19 & 20 & 21 & 17 & 15 & 15 & 16 & 18 & 18 & 217 \\
Madrid & 11 & 17 & 22 & 23 & 27 & 29 & 31 & 31 & 28 & 21 & 14 & 11 & 265 \\
Very dry days & & & & & & & & & & & & & \\
\hline Station & I & II & III & IV & V & VI & VII & VIII & IX & X & XI & XII & I-XII \\
Alicante & 5 & 6 & 8 & 7 & 6 & 6 & 4 & 4 & 3 & 4 & 5 & 2 & 60 \\
Madrid & 1 & 4 & 9 & 10 & 15 & 25 & 30 & 30 & 22 & 7 & 2 & 1 & 157 \\
\hline
\end{tabular}

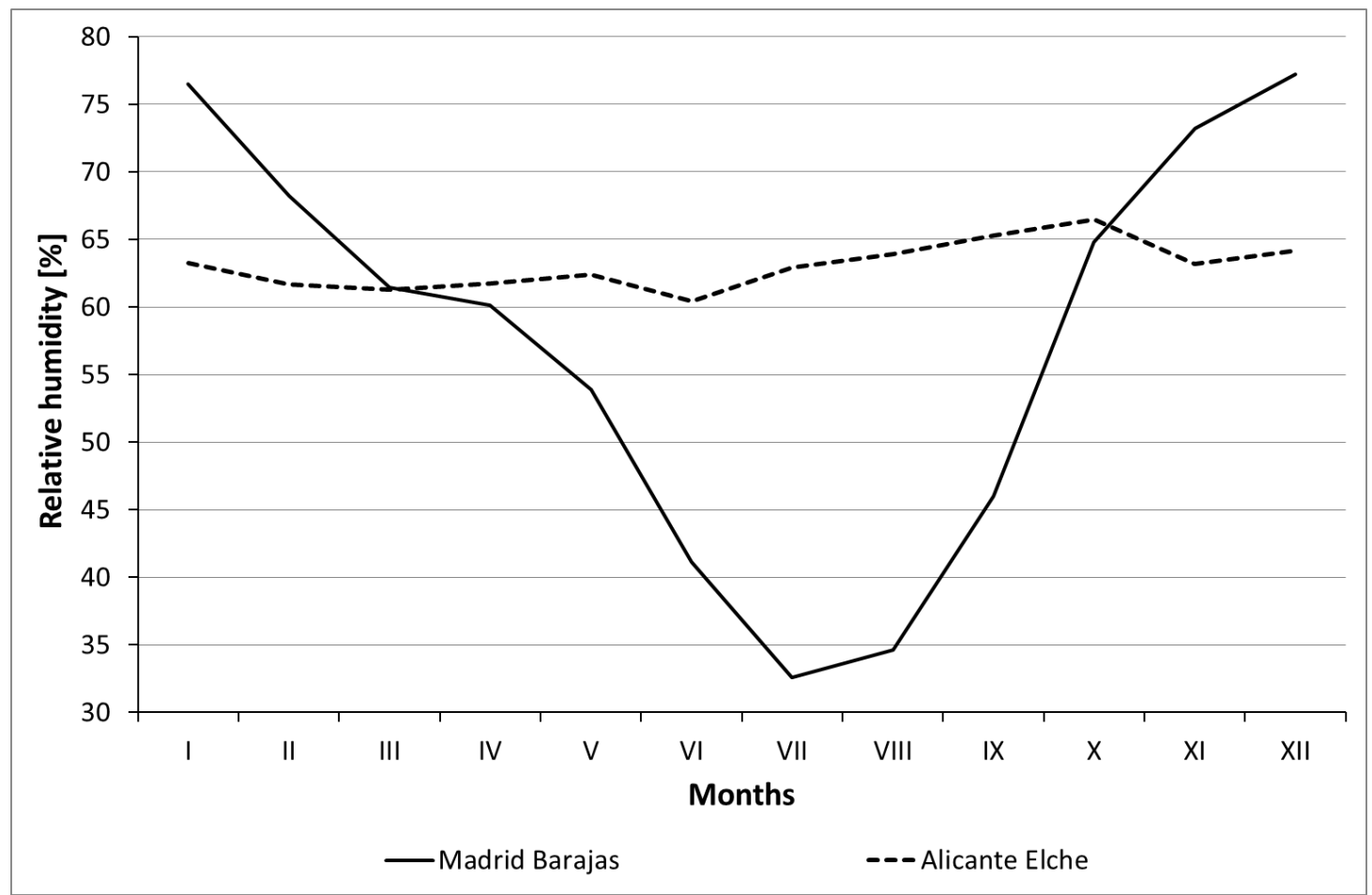

Fig.4. Annual course of relative humidity in the period 2000-2014. 
Annual average precipitation in Spain shows high spatial variability. Highest values (above $2200 \mathrm{~mm}$ ) are seen in the mountainous areas of north-eastern Continental Portugal, in the northeast of Navarra and in some areas of the south-western Galicia. In period 1971-2000, the highest annual rainfall was noted in Vigo (1920 mm), San Sebastian (1565 mm), Bilbao $(1155 \mathrm{~mm})$ and Santander $(1136 \mathrm{~mm})$. The lowest annual precipitation was recorded in the southeast of Spain, especially in the provinces of Almeria (196 mm), Murcia (300 mm) and Alicante (336 mm) (Tab. 4). Low precipitation in the east coast of Spain is caused by, dominating summer, south-eastern winds blowing from over the Sahara Desert. The air masses drifted by this winds have relatively low water vapour content due to their short track over a narrow strip of the Mediterranean Sea. Therefore, those winds are very dry and contain a lot of dust from the African desert (Martyn 1992).

\section{Monthly precipitation}

Currently in Madrid (2000-2014), the highest monthly precipitation, occurs in October (64.2 $\mathrm{mm})$ and November $(45.1 \mathrm{~mm})$ as in Alicante
(October $36.7 \mathrm{~mm}$, November $32.8 \mathrm{~mm}$ ). Equally high precipitation totals are also noted in September $(35.8 \mathrm{~mm})$. At both stations summer is the driest season. In Alicante, June, July and August precipitation amounted to 5.9 $\mathrm{mm}, 3.5 \mathrm{~mm}$ and $7.3 \mathrm{~mm}$, respectively. In Madrid, in the same part of the year, monthly precipitation amounted to $17.7 \mathrm{~mm}$ (June), 5.6 $\mathrm{mm}$ (July) and $5.3 \mathrm{~mm}$ (August) (Tab. 3).

\section{The maximum daily precipitation}

In the period 2000-2014, despite relatively low monthly precipitation totals, very high daily precipitation was recorded. In Madrid the maximum daily precipitation amounting to 57.3 $\mathrm{mm}$ was recorded on $22^{\text {nd }}$ September 2008. In Alicante absolute daily maximum occurred on $28^{\text {th }}$ September 2009 one and reached $58.8 \mathrm{~mm}$. On $28^{\text {th }}$ September 2009 Spain was located between a thermal low-pressure system located over the Sahara Desert, and low-pressure system situated close to Ireland which caused abundant precipitation over the whole east coast of Iberian Peninsula. The maximum daily precipitation in Madrid occurred under an influence of cyclonic trough extending from the west coast of the Iberian Peninsula throughout

Tab.3. Monthly and annual average precipitation [mm] in period 1961-1990 and 2000-2014.

\begin{tabular}{|c|c|c|c|c|c|c|c|c|c|c|c|c|c|c|}
\hline Station & Period & I & II & III & VI & $\mathrm{V}$ & VI & VII & VIII & IX & $X$ & XI & XII & I-XII \\
\hline \multirow[t]{3}{*}{ Alicante } & 1961-1990 & 20.0 & 27.0 & 25.0 & 34.0 & 32.0 & 23.0 & 4.0 & 8.0 & 41.0 & 66.0 & 42.0 & 34.0 & 356.0 \\
\hline & 2000-2014 & 19.5 & 12.0 & 18.3 & 29.4 & 24.0 & 5.9 & 3.5 & 7.3 & 35.8 & 36.7 & 32.8 & 19.7 & 245.7 \\
\hline & $\%$ of Normals & 97 & 45 & 73 & 87 & 75 & 26 & 88 & 92 & 87 & 56 & 78 & 58 & 69 \\
\hline \multirow[t]{3}{*}{ Madrid } & 1961-1990 & 42.0 & 45.0 & 30.0 & 45.0 & 39.0 & 26 & 9.0 & 9.0 & 28.0 & 38.0 & 59.0 & 44.0 & 414.0 \\
\hline & $2000-2014$ & 28.2 & 32.5 & 33.1 & 35.4 & 36.2 & 17.7 & 5.6 & 5.3 & 23.7 & 64.2 & 45.1 & 36.1 & 364.1 \\
\hline & $\%$ of Normals & 67 & 72 & 111 & 79 & 93 & 68 & 62 & 59 & 85 & 169 & 77 & 82 & 88 \\
\hline
\end{tabular}

Tab.4. Annual precipitation totals [mm] in Spain in the period 1971-2000 (AEMET 2012).

\begin{tabular}{|c|c|c|c|c|c|c|c|}
\hline Station & Pavg. & $\operatorname{Max}$ & Year & Station & Pavg & Min & year \\
\hline Vigo/Peinador & 1919.7 & 2494.1 & 1977 & Almeria Airport & 195.9 & 64.9 & 1998 \\
\hline San Sebastian & 1564.8 & 2206.3 & 1979 & Murcia & 300.6 & 115.2 & 1995 \\
\hline Bilbao Airport & 1155.1 & 1571.1 & 1979 & Alicante & 335.7 & 108.9 & 1995 \\
\hline
\end{tabular}


the whole Mediterranean Sea. Although there was no clear low-pressure area on that day, the cyclonic trough caused abundant precipitation in Madrid. In years 1971-2000, the highest maximum daily precipitation (09-09 UTC by AEMET) occurred in Alicante on 30 September 1997, and amounted to $270.2 \mathrm{~mm}$ (AEMET 2012). This daily total exceeded the annual precipitation for the period 2000-2014. Furthermore, during the flooding of Valencia Province in October 1957 in Bejis (Valencia) the precipitation of $210 \mathrm{~mm}$ fell during $90 \mathrm{~min}$. and $361 \mathrm{~mm}$ during 24 h (Linés Escardó 1970).

\section{Climate change in tendencies in Madrid and Alicante}

\section{Air temperature}

The annual air temperature in the period 20002014 was higher than in the reference period $1961-1990$ (WMO 1996) by about $0.2^{\circ} \mathrm{C}$ in Alicante and $0.9^{\circ} \mathrm{C}$ in Madrid. This increase indicates warming of the climate of this area. It is noteworthy that contemporary winters (20002014) are colder than those in the 1961-1990 period at both stations. In Alicante deviation of monthly temperature from CLINO normal reached about -0.2 in November, -0.3 in December , -0.4 in January and -0.8 in February. At the Madrid station air temperature in December, January and February is currently lower by about $-0.4^{\circ} \mathrm{C},-0.1^{\circ} \mathrm{C}$ and $-0.3^{\circ} \mathrm{C}$ respectively (Tab. 1). The increase in annual temperature and simultaneous decrease in winter air temperature can be considered as a specifics manifestation of climate change at both stations. The character of changes in Spanish winter temperature is different than that observed in Central Europe, where this season is rapidly shortening in recent years (Czernecki and Miętus 2015).

\section{Precipitation}

In the period 1961-1990 the annual total amounted to $356.0 \mathrm{~mm}$ in Alicante and 414.0 $\mathrm{mm}$ in Madrid. In the normal period of 19712000 (AEMET 2012) annual precipitation was lower than earlier (1961-1990) and reached $335.7 \mathrm{~mm}$ in Alicante and $435.8 \mathrm{~mm}$ in Madrid
On the southeastern coast of Spain, in the period 2000-2014, the annual precipitation is lower by about $110 \mathrm{~mm}$ comparing to the normal period of 1961-1990. In the interior of Iberian Peninsula, the annual precipitation is lower by about $49.9 \mathrm{~mm}$ in the period 2000-2014 than in 1961-1990. At both station a clear decrease in annual totals since 1961-1990 is visible, particularly in Alicante (Tab. 3).

\section{Concluding remarks}

In this paper the contemporary climatic conditions of two meteorological stations were discussed. These stations are located in the central part of Spain (Madrid Barajas) and on the south-eastern coast (Alicante Elche). Three climatic elements were analysed - air temperature, relative humidity and precipitation - for years 2000-2014.

According to Köppen climate classification from 1936, also known as the Köppen-Geiger Classification System (AEMET 2012), the area of Madrid belongs to a group of Temperate Climate (type Csa) with dry (letter s) and hot summer (letter a) in with the average temperature in the hottest month exceeding $22^{\circ} \mathrm{C}$. In turn, the Alicante has the climate of type B (dry climate) and sub-type BW (desert). Due to low annual precipitation, the climate of Alicante also falls into type BSk (cold desert) and semi-dry climate. The location of Madrid and Alicante results in different climatic conditions of these locations. The Madrid Barajas Airport is characterized by continental climate, whereas the station in Alicante have a mild marine one.

In the period of 2000-2014, annual average air temperature was lower by about $3.3^{\circ} \mathrm{C}$ in Madrid than in Alicante. In the continental climate of Madrid daily temperature range which vary in a wide extend from $9.8^{\circ} \mathrm{C}$ in January to $16.7^{\circ} \mathrm{C}$ in July. In contrast, the mild marine climate of Alicante is characterized by much lower daily temperature range reaching about $8.9^{\circ} \mathrm{C}-10.3^{\circ} \mathrm{C}$, in all months. In the period 2000-2014, relative humidity reached $33 \%$ in summer season and $77 \%$ in winter months in Madrid, while in Alicante it ranged from $60 \%$ to $66 \%$. In Madrid, monthly average rainfalls are the highest in October and 
November, while their biggest deficit occurs in July and August. In Alicante the highest monthly rainfalls were recorded in September, October and November and these totals were lower than analogues ones in Madrid. The lowest monthly precipitation is recorded in the summer season (Jun-Aug) particularly in Alicante. The south-east is the driest area in Spain, where annual average precipitation does not exceed $250 \mathrm{~mm}$.

In the period 2000-2014, the annual average air temperature is higher by about $0.9^{\circ} \mathrm{C}$ in Madrid and $0.2^{\circ} \mathrm{C}$ in Alicante than it was in the years 1961-1990. It was found that in the contemporary period winters are cooler than in the earlier period of 1961-1990. Generally, monthly average air temperatures from November to February are currently higher than in years 1961-1990 at both stations. In majority of months the average precipitation, in the years 1961-1990 and 1971-2000 was higher than in 2000-2014. At Alicante station contemporary monthly rainfall are lower compared to the both normal periods 1961-1990 and 1971-2000. The highest annual precipitation was that for the period 1961-1990 and amounted to $356 \mathrm{~mm}$ in Alicante and $414 \mathrm{~mm}$ in Madrid. In the latter of the normal periods (1971-2000) annual precipitation amounted to $336 \mathrm{~mm}$ in Alicante and $436 \mathrm{~mm}$ in Madrid.

\section{References}

AEMET (2012) Atlas Climatico IbéricoIberian Climate Atlas, Agencia Estatal de Meteorologia (AEMET), Ministerio de Agricultura, Alimentación y Medio Ambiente, Instituto de Meteorologia de Portugal, NIPO: 281-12-006-X (in Portuguese, Spanish and English). (Website: $\quad 2012$ http://www.aemet.es/documentos/es/cono cermas/publicaciones/Atlasclimatologico/ Atlas.pdf).

Braganza K., Karoly DJ., Arblaster JM. (2004) Diurnal temperature range as an index of global climate change during the twentieth century. Geophysical Research Letters (in print). $\quad 31, \quad 13, \quad$ DOI: 10.1029/2004GL019998.
Brunet M., Jones P.D., Sigró J., Saladié O., Aguilar E., Moberg A., Della-Marta P.M., Lister D., Walther A., López D. (2007) Temporal and spatial temperature variability and change over Spain during 1850-2005. Journal of Geophysical Research: Atmospheres (1984-2012), 112 ,D12.

Czernecki B., Miętus M. (2015) The thermal seasons variability in Poland, 1951-2010. Theoretical and Applied Climatology (in print).1, 13, DOI:10.1007/s00704-0151647-z.

Del Rio S., Fraile R., Herrero L., Penas A. (2007) Analysis of recent trends in mean maximum and minimum temperatures in a region of the NW of Spain (Castilla $\mathrm{y}$ León). Theoretical and Applied Climatology. 90, 1-2, 1-12.

Gallego M.C., García J.A., Vaquero J.M., Mateos V.L. (2006) Changes in frequency and intensity of daily precipitation over the Iberian Peninsula. Journal of Geophysical Research: Atmospheres (1984-2012). 111 ,D24.

Goodess C.M., Palutikof J.P. (1998) Development of daily rainfall scenarios for southeast Spain using a circulation-type approach to downscaling. International Journal of Climatology. 18, 10, 1051-1083.

Kenawy A.El., López-Moreno J.I., VicenteSerrano S.M. (2012) Trend and variability of surface air temperature in northeastern Spain (1920-2006): Linkage to atmospheric circulation. Atmospheric Research. 106, 159-180.

Klein Tank A.M.G., and Coauthors (2012) Daily dataset of 20th-century surface air temperature and precipitation series for the European Climate Assessment. International Journal of Climatology. 22, 1441-1453. (Database available on website: http://www.ecad.eu.)

Linés Escardó A. (1970) The Climate of the Iberian Peninsula. [In:] Climate of Northern and Western Europe. Chapter 5 (ed. C.C. Wallén). World Survey of Climatology. Volume 5. Elsevier 
Publishing Company, AmsterdamLondon-New York, 195-239.

Martin-Vide J., Lopez-Bustins J.A. (2006) The western Mediterranean oscillation and rainfall in the Iberian Peninsula. International Journal of Climatology. 26, $11,1455-1475$.

Martyn D. (1992) Climates of the World. PWN-Polish Scientific Publishers, Warszawa, and Elsevier, AmsterdamOxford-New York-Tokyo, $435 \mathrm{pp}$.

Martyn D. (1995) Climate of the World (Klimaty kuli ziemskiej). Wydanie II zmienione. Wyd. Naukowe PWN, Warszawa (in Polish).
Rodrigo F.S. (2010) Changes in the probability of extreme daily precipitation observed from 1951 to 2002 in the Iberian Peninsula. International Journal of Climatology. 30, 10, 1512-1525.

WMO (1996) Climatological Normals (CLINO) for the period 1961-1990, WMO/OMM-No. 847, GenevaSwitzerland.

Valor G.B., López D. J.M.G. (2015) OGIMET-professional information about meteorological conditions in the world, Internet address: http://www.ogimet.com/. 